\title{
Diversidade e afrodescendência: mediações, interações e (re)conhecimento
}

Transcrição do discurso da Ministra Chefe de Estado do Ministério das Mulheres, da Igualdade Racial e dos Direitos Humanos, Nilma Lino Gomes, na abertura da Quarta Semana da UEMG.

Há acordo entre nós que a função da universidade pública é garantir ensino, pesquisa e extensão. Nos últimos anos, há quem advogue que a esses três deva se somar a um quarto: a internacionalização.

É importante que a prática e a política universitária sejam constituídas e/ou caracterizadas por esses três ou quatro pilares. No entanto, um olhar na perspectiva da promoção da igualdade racial nos leva a crer que, diante das recentes mudanças, consequentes da luta por democratização do acesso à graduação e à pós-graduação, que se traduziram em medidas inclusivas e políticas de ações afirmativas, uma outra função da universidade pública está colocada: o reconhecimento e o trato digno da diversidade.

Embora, a diversidade seja uma característica do humano, nem sempre recebe uma leitura positiva quando os coletivos sociais considerados diversos reivindicam seus direitos à diversidade, principalmente, quando revelam para a sociedade e para o Estado que diversidade e desigualdade se articulam e que não podemos pensar uma sem levar em conta a outra.

O que isso quer dizer? 2) - que a sociedade em que vivemos é desigual e ao mesmo tempo possui uma diversidade cultural, étnica, racial, de gênero que se constrói nos contextos das relações de poder.

b) - as relações de poder na sociedade podem hierarquizar e discriminar a diversidade.

Mas, o que estamos chamando de diversidade? Segundo Nilma Gomes, é a construção histórica, social, cultural e econômica das diferenças.

Diferenças essas construídas nas relações sociais e de poder. Como nos diz o antropólogo Carlos Brandão, muitas vezes inventamos o outro, o diferente para poder discriminá-lo. E é justamente contra esse trato 
discriminatório e desigual da diversidade que os movimentos sociais, mais precisamente, a partir do século $X X$, passaram a se contrapor.

Inicialmente, a ênfase recaía sobre os direitos dos trabalhadores ao salário e às condições dignas do voto da mulher, do voto do analfabeto, direito à moradia, à terra, à saúde, à educação e, mais no final do século XX e início do século XXI, o direito à diversidade.

São os movimentos sociais de caráter identitário que trouxeram debates sobre a diversidade e o direito à diferença para a nossa sociedade, problematizando que o recorte socioeconômico era insuficiente para compreender o Brasil e construirmos justiça social.

Entre esses movimentos sociais citamos as ações dos movimentos negros, das mulheres, dos indígenas, das pessoas do campo, das pessoas com deficiência, da população LGBT, que problematizaram e problematizam não só o lugar subalterno em que algumas diferenças - no complexo contexto da diversidade - têm sido historicamente colocadas e como os sujeitos dos coletivos sociais que as expressam são considerados desiguais, inferiores e no limite do não humanos.

Esse olhar problematizador trouxe desconforto para muitos setores da sociedade, explicitou relações de poder que hierarquizavam relações, indagou discursos antes vistos como verdades e apontou novos caminhos.

O movimento negro é um dos que merece ser lembrado, destacado. Primeiro, porque conseguiu divulgar para setores pobres da sociedade as descobertas da ciência de que a África e, não a Europa, é o berço da humanidade. Essa descoberta científica que limitada aos fóruns acadêmicos e às instituições de ensino passou a ser um ensinamento popular e o que isso nos trouxe?

No imaginário social, esse reconhecimento da ciência, considerada fonte legítima do saber por grande parte da sociedade, colocou a todos nós, brasileiros e brasileiras, no complexo terreno da afrodescendência. Ao reconhecer que a humanidade descente da África, uma inflexão acontece no nosso pensamento e nas nossas operações mentais.

Trata-se de um processo muito lento, mas que surte efeito indentitários e de reconhecimento. Além disso, o movimento negro trouxe uma problematização a mais: não basta se reconhecer e ser afrodescendente 
para se compreender e superar um perverso fenômeno que existe entre nós: o racismo.

Para se compreender e superar o racismo, é preciso mais do que reconhecimento. É necessário saber as diferentes formas como ele opera, qual é a sua relação com as desigualdades e como esse fenômeno afeta o processo de construção das identidades.

A afrodescendência é um reconhecimento do nosso elo ancestral com o continente africano, de um passado que faz parte de todos nós. E é dentro da afrodescendência que identidades raciais e étnicas são construídas. A identidade negra é uma delas. Logo, ser negro não é somente reconhecer a ancestralidade africana em nós. É participar da construção política da identidade negra, tornar-se negro, diria Neusa Santos Souza. Identidade essa que se revela nos sinais diacríticos do corpo na nossa corporeidade de forma tão complexa, que pode, inclusive, ser uma escolha política. Não se trata de uma escolha oportunista. Ser negro e saber ser negro significa assumir viver as dores do racismo e os efeitos positivos do reconhecimento e da afirmação.

Implementação das políticas de ações afirmativas na sociedade brasileira, com recorte para o segmento negro da população, é um momento oportuno para entender como a afrodescendência, identidades, reconhecimento passaram a fazer parte das preocupações políticas e acadêmicas do nosso tempo.

A política de cotas, por exemplo, traz para a universidade novos questionamentos, um novo quadro acadêmico, sujeito com saberes, cores, roupas, origens, culturas, vocabulários diferentes. A diversidade começa, aos poucos, a ser vista em diferentes turmas e cursos. Os docentes, aos poucos também. No campo do conhecimento crescem pesquisas principalmente nas ciências sociais e humanas - que discutem as relações étnico-raciais, as desigualdades raciais e o racismo.

As pesquisas revelam que a presença negra aumentou nas universidades públicas que adotaram ações afirmativas. Hoje, é comum ouvirmos a frase: "o filho da empregada vai virar doutor!" Talvez devêssemos dizer que, com as cotas raciais, o filho negro da empregada negra vai virar doutor. A filha negra da empregada negra vai virar 
doutora. E já podemos ver algumas delas, alguns deles ocupando espaços por aí.

E os desafios que esse contexto traz para a universidade? Diria que, ao implementar as ações afirmativas dana modalidade de cotas, a universidade precisa estabelecer novas mediações, outras interações e compreender o tenso processo de reconhecimento. Não basta apenas a universidade cumprir a lei estadual e federal e não se reinventar por dentro, como nos diz Miguel Arroyo. Mediações entre os diferentes sujeitos que hoje fazem parte da vida acadêmica e suas diferenças, interações entre suas diferentes áreas de conhecimento e entre diferentes sujeitos, mediações quando conflitos entre sujeitos e suas vivências surgem no interior da universidade, interações entre disciplinas, docentes e currículos. Como pode uma universidade passar por mudança estrutural como a política de cotas e outras medidas de ações afirmativas e não reestruturar seus currículos? Não reorganizar a forma como o reconhecimento é trabalhado, vivido? Não reconhecer que os sujeitos diversos trazem conhecimentos diversos? E que a troca e encontro de conhecimento nem sempre são harmoniosas, pois nos trazem tensões e conflitos que, como educadores, pesquisadores e gestores, temos que saber administrar? Ou, pelo menos, construir outro tipo de docência, de pesquisa e de gestão que passem a interagir com esses sujeitos e seus conhecimentos?

Todo esse processo passa pelo reconhecimento de que os sujeitos diversos nos forçam a reinventar a universidade clássica e suas estruturas conservadoras. Colocam-nos diante do desafio de reconhecê-los não somente como sujeitos dos conhecimentos, mas também superar a perversa forma como o racismo nos ensinou a vê-los. Ou seja, nos obriga a nós, a universidade, ao Estado e a sociedade, a reconhecê-los como humanos.

A Semana da UEMG é uma boa oportunidade para discutirmos sobre isso. Espera-se que as iniciativas de extensão e pesquisa das universidades públicas em tempos de ações afirmativas e reconhecimento das diversidades sejam tão criativas e impactantes como são as políticas. É expectativa que temos o trabalho da UEMG e que essa semana poderá revelar à comunidade, dentro e fora da universidade. 